Cinémas

Revue d'études cinématographiques

Journal of Film Studies

\title{
Multifunctional Halls and the Place of Cinema in the European \\ Countryside, 1920-1970
}

\section{Les salles multifonctionnelles et la place du cinéma dans la \\ campagne européenne, 1920-1970}

\section{Judith Thissen}

Volume 27, numéro 2-3, printemps 2017

Les salles de cinéma. Histoire et géographie

URI : https://id.erudit.org/iderudit/1045369ar

DOI : https://doi.org/10.7202/1045369ar

Aller au sommaire du numéro

Éditeur(s)

Cinémas

ISSN

1181-6945 (imprimé)

1705-6500 (numérique)

Découvrir la revue

Citer cet article

Thissen, J. (2017). Multifunctional Halls and the Place of Cinema in the European Countryside, 1920-1970. Cinémas, 27(2-3), 91-111.

https://doi.org/10.7202/1045369ar
Résumé de l'article

Prenant pour point de départ et d'arrivée la question « qu'est-ce qu'un cinéma ? ", et reconsidérant la notion de seconde naissance du cinéma, cet article étudie les rapports économiques et socioculturels de l'exploitation et de l'expérience cinématographiques dans les petites villes et les zones rurales d'Europe occidentale, en particulier aux Pays-Bas, en Allemagne et en France. L'accent est mis sur l'histoire du cinéma ambulant présenté dans des lieux multifonctionnels dans la période qui a suivi celle des foires - un aspect important de la culture cinématographique européenne qui a longtemps été négligé par les historiens du cinéma. Un aperçu de ces expériences particulières du cinéma peut nous aider à reconsidérer la place de ce dernier dans les contextes ruraux et urbains. Un aspect crucial de la projection de films est le fait qu'elle prenait place dans des lieux multifonctionnels, c'est-à-dire des espaces utilisés pour un large éventail d'activités commerciales et communautaires. L'auteur préconise ainsi une nouvelle historiographie du cinéma qui rompt avec la fixation sur la singularité du médium pour inclure sa relation avec les contextes socioculturels environnants dans lesquels il prend place. 


\title{
Multifunctional Halls and the Place of Cinema in the European Countryside, 1920-1970
}

\author{
Judith Thissen
}

\begin{abstract}
Beginning and ending with the question "what is a cinema?" and with a reconsideration of the notion of cinema's second birth, this article examines the economic and socio-cultural dynamics of film exhibition and film-going in small-town and rural Western Europe, in particular in the Netherlands, Germany and France. Emphasis is placed on the history of itinerant film exhibition in multifunctional venues in the period after the era of the fairground shows - an important aspect of European film culture which has long been overlooked by cinema historians. Insights from these particular experiences of the cinema can help us to reconceptualize the place of cinema in both rural and urban contexts. A crucial aspect of film-going in multifunctional venues is the fact that it was located in spaces that were used for a wide range of commercial and community activities. The author thus advocates a new cinema historiography that breaks away from the fixation on the medium's singularity to include its relation with the surrounding socio-cultural contexts in which cinema happened.
\end{abstract}

\section{Prelude: Ceci n'est pas un cinéma?}

What is a cinema? For many inhabitants of Saint-Laurent-duMédoc in the rural Gironde, the community hall on the Place de la Mairie (fig. 1) was the place where they went "au ciné." Except for the billboard in front of the entrance, however, there is no other indication that identifies the building's function as a film venue. In fact, the hall was genuinely multipurpose because it served not only as a movie theatre, salle des fêtes and foyer familial, but also housed the public baths and accommodated the fire brigade. At the same time, its strikingly modernist façade and the use of concrete echo the architecture of the many purpose-built 


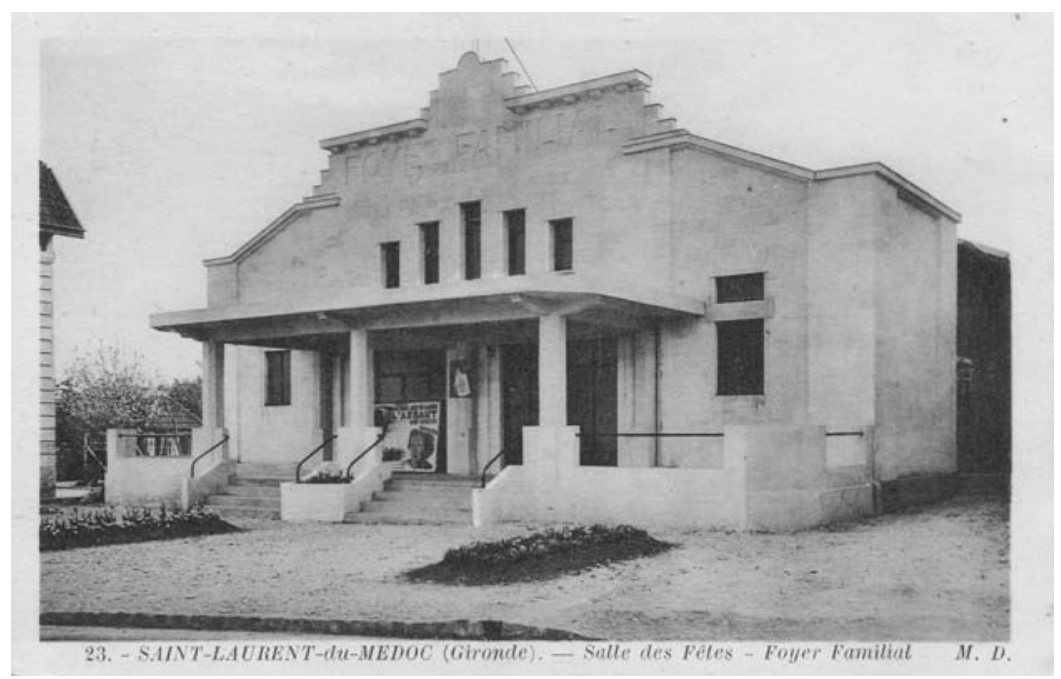

Fig. 1. Postcard, salle des fêtes, Saint-Laurent-du-Médoc, posted 1942.

cinemas that opened in small-town France during the interwar years. The art deco hall sharply contrasted with the immediate surroundings and conveyed a message of local pride and modernity. The photograph was probably taken not long after the opening in 1937, when the town had a population of just over 2,000. On the program that week was L'Assaut (Jean-Pierre Ducis, 1936). French productions usually reached the countryside within a year or two. Most likely the hall was part of an itinerant circuit and the film was shown for just one night. Many municipal halls in rural communities were operated by travelling exhibitors, who had a route of localities that they visited each week on a fixed day with a new set of films. The smallest villages were served less often. According to figures published by the Centre national du cinéma (CNC), hundreds of itinerant exhibitors were active in France well into the 1950s.

Equally important as outlets for film exhibition in the European countryside were multifunctional halls that belonged to café-restaurants and inns/hotels. From the early days of the cinematograph, these venues have been used by itinerant showmen, in small towns and villages as well as in larger towns and cities. After the arrival of permanent cinemas in the bigger localities, they remained a stronghold of rural film exhibition. In this 
second category of multifunctional venues, we find a wide range of setups and sizes. They vary from very modest barn-like spaces with wooden benches to true theatrical auditoria that seated 400-600 people, sometimes even more. Let me take the example of the Gasthof zum Hofgarten (fig. 2) in Hückeswagen, a small town in the industrialized countryside near Cologne, Germany. The publicity postcard for this establishment tells us that it served food, had guest rooms, a large hall, smaller meeting rooms, a nice garden and offered film screenings (Lichtspiele). Starting in 1919, the main hall with around 400 seats was operated as a semi-permanent movie theatre for almost five decades. Like on the postcard of Saint-Laurent-duMédoc, it is the billboard and display case outside the building that reveal its function as a cinema. But in contrast to the modernist municipal hall, the vernacular architecture of the inn and its multipurpose hall blended in seamlessly with the surroundings. Hence, to the extent that the show started "on the sidewalk," cinema's relation to urban modernity was less conspicuous. When the photograph was taken, the program was showing . . . nur ein Komödiant (Only a Comedian), an Austrian film directed by Erich Engel in 1935. Screenings in inns, hotels and cafés were often set up by an itinerant exhibitor, whereby the landlord received a rental fee and/or a percentage of the

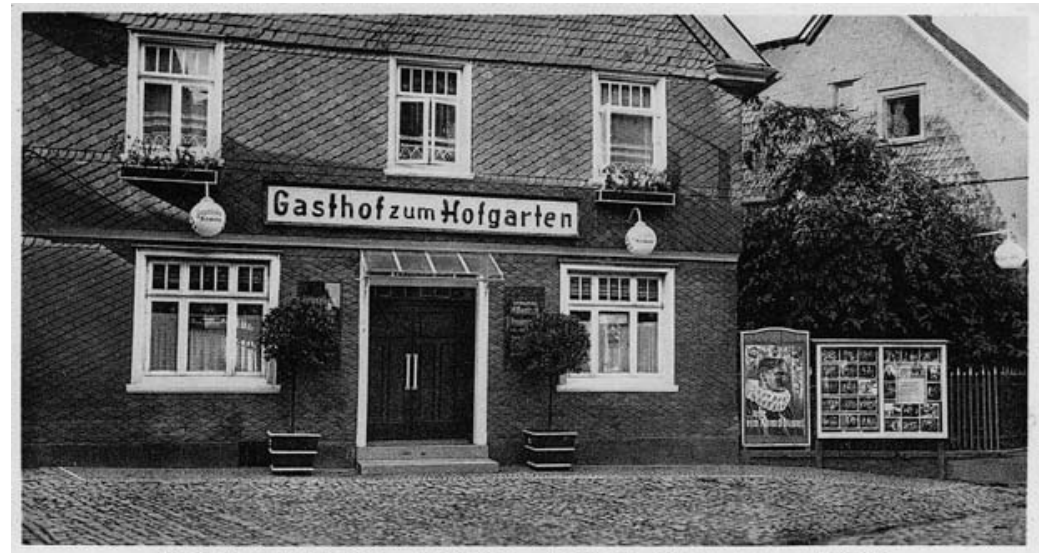

Gasthof zum Hofgarten - Lichtspiele - W. Knautz. Hückeswagen - Ruf 243

Großer Saal, Gesellsehaftszimmer, schattiger Garten - Pension, Fremdenzimmer - Kalte u. warme Speisen zu jeder Tageszeit

Fig. 2. Postcard, Gasthof zum Hofgarten, Hückeswagen, circa 1935. 
turnover. Others kept the organization and commercial benefits of the "movie nights" in their own hands. The owner of Gasthof zum Hofgarten had actually started out as a film exhibitor and then became an innkeeper. Depending on the size of the community and local demand, cinema halls like the Hofgarten Lichtspiele operated on a once-a-week basis or semipermanently (Friday-Monday).

The stories behind the two postcards raise a number of issues that I will explore in this article. To begin with, both examples evidently challenge the conventional notion of what a moving picture theatre is and call for a more inclusive reading of the history of film exhibition and consumption - a history that does not marginalize the countryside. Moreover, they draw our attention to a mode of film-going in which the institution of the cinema is closely intertwined with other leisure-time practices and subject to different economic and ideological forces than the mainstream urban model of the movie theatre. At the same time, there are important differences between the two examples in the way the relation to rural modernization is articulated. The municipal halls like the one in Saint-Laurentdu-Médoc were part of a public effort at rural transformation, as attested by its modernist architecture. They were not-forprofit halls that incorporated commercial screenings of the latest entertainment medium to sponsor communal activities that were rooted in traditional community structures. By contrast, the cinema hall of the Gasthof zum Hofgarten was a commercial activity in a commercial establishment. Still, the screenings in the hotel-restaurants and cafés were also embedded in traditional forms of sociability (drinking, eating, dancing etc.). And the proprietors were typically part of the local community, often for many generations, unlike the itinerant exhibitor, who by definition was an outsider.

Focusing on the Western European countryside, this contribution on commercial film exhibition in multipurpose halls draws its insights from my own archival research on rural 
movie-going and the published work of other scholars. As I have argued elsewhere (Thissen 2013), if we want to fully understand national and transnational dynamics in European film history, it is necessary to integrate local, regional and national studies into broader comparative frameworks. The main focus will be on the Netherlands, (West) Germany and France. To break away from the traditional focus on early cinema, when multifunctional halls were a major outlet for the new film medium in urban and non-urban contexts alike, I will primarily discuss the period from the 1920s until the late 1960s, when the phenomenon of itinerant film exhibition usually disappears from national film statistics. Although the cut-off point remains open for further exploration and may have varied regionally, the available evidence strongly suggests that the combination of the breakthrough of television, the emergence of new forms of public leisure and increased mobility marked the end of for-profit film exhibition in multifunctional venues. What we see developing in return are ciné-clubs and screenings in subsidized cultural centres with facilities for film projection and with an offering that often tends towards an art house repertoire and other non-mainstream content. This alternative film scene partly built upon the earlier tradition of not-forprofit screenings run by religious, educational and political organizations (Thissen and Zimmermann 2016). These developments are not examined here, however, because this article focuses exclusively on for-profit film exhibition.

\section{Cinema Was Not Always Born Twice}

In the historiography of movie-going, commercial film screenings in multifunctional halls have been generally overlooked because they were a predominantly rural and small-town phenomenon and film scholarship has long focused almost exclusively on film culture in the big cities (Allen 2008, FullerSeeley 2008). In the standard accounts, then, these outlets disappear to the margins of the for-profit film exhibition sector in the 1910s, when more and more stationary movie theatres opened their doors in cities and larger towns across Europe and North America. However, a growing body of New Cinema 
History research and a rediscovery of older publications about regional cinema challenge this dominant narrative. As Kathryn H. Fuller-Seeley and George Potamianos (2008, p. 6) point out, the narrow focus on urban cinema has led "towards broad generalizations that begin to look less solid when we observe cinema's emergence from other angles, those of the local, the peripheral, through specific empirical case studies."

First, recent research on small-town and rural film culture reveals the continued importance of itinerant and semipermanent film exhibition in the European hinterlands after the "classical era" of the travelling cinema (Thissen and Zimmermann 2016). Let us look at a few figures to get a sense of the scale. In West Germany in 1953, there were 335 itinerant film exhibitors serving 3,569 venues. Half of them operated in the $35 \mathrm{~mm}$ segment of the market, the others showed $16 \mathrm{~mm}$ films. In addition, 1,370 multifunctional halls were supplied with a weekly changing program by the proprietors of permanent movie theatres, a system in which the halls were considered a subsidiary of the main venue (so-called Mitspielstellen). In sum, West Germany counted nearly 5,000 multifunctional film outlets operating within the mainstream distribution system (Faber 1957, pp. 30-33). In France, this segment of the market was equally important in terms of numbers. In fact, $16 \mathrm{~mm}$ operators served even more localities than $35 \mathrm{~mm}$ theatres. Just after the Occupation, the Centre national de la cinématographie issued 5,300 licences for $16 \mathrm{~mm}$ projection. The large majority were for commercial ventures, including 2,748 itinerant film exhibitors (Forest 1995, pp. 79-80). In the post-war Netherlands, 16 itinerant businesses were active in the $35 \mathrm{~mm}$ market. Together, they served around 300 communities. In comparison, 271 Dutch municipalities had at least one permanent movie theatre (van Oort 2016; Dibbets 1980, pp. 59-60 and 85).

Second, the research on rural cinema draws our attention to the diversity of dispositifs in which audiences encountered the movies when they lived in villages and hamlets, or in small towns without a permanent cinema. What these rural and semirural contexts of film consumption shared is a continued inter- 
relationship between film culture and other realms of social life, entrepreneurial activity and cultural practices. The multifunctional halls were used for balls, parties and dances, performances by (amateur) theatre groups, singing clubs and local bands, gymnastics, lectures and political meetings. Many of these activities were not-for-profit, family-oriented events with firm roots in the social and cultural life of the community as well as in grassroots voluntary organizations. Initially, a similar permeability of film consumption, other forms of entertainment and civic society characterized the experience of the new film medium in the city (Braun $e t a l$. 2012). In the mainstream urban markets, however, the boundaries between the film medium and other socio-cultural institutions and leisure practices were redressed during "cinema's second birth," that is, the phase during which the film medium found its singular identity "as a new medium of expression" with its own clearly demarcated production and viewing practices (Gaudreault and Marion 2005, p. 4).

From the vantage point of film exhibition history, Paul Moore (2013, pp. 114-15) points out that it is above all the emergence of the movie theatre as "an autonomous social space distinct from other entertainments" that characterizes cinema's second birth. Until then, "moving picture attractions circulated as a supplement to an unpredictable range of possibilities, locations and occasions, each attached to pre-existing social institutions and collective rituals." With the opening of the movie theatre, he argues, this multiplicity was replaced by institutional singularity. Applied to the European countryside, however, this argument does not hold. In many small towns and villages, the movies never found "a place of their own" and hence film exhibitors continued to "squat" in other venues. Put differently, for much of the twentieth century, the permanent movie theatre never was the dominant dispositif in which films were watched by consumers in the country. These conceptualizations of cinema's double birth, then, when carefully historicized, imply that the cinematic apparatus only became a fully-fledged medium in the city or at best in North America. Do we have to conclude that large numbers of rural and small-town folks in Europe never went to the cinema? Perhaps we had better ask ourselves 
anew: What is a cinema? I will come back to this question in my conclusion. First we will look at the scholarship on nonmetropolitan film exhibition and consumption, whereby the aim is not a comprehensive survey, but an effort to define the central dynamics of rural film culture.

\section{A Divided Market}

As Anne Paech (1985, p. 84) notes in her pioneering work on regional film exhibition in Germany, the cinema infrastructure in the hinterlands was fundamentally different from that in the city because the market was divided between stationary and travelling exhibitors. Although our main concern is with the latter, we cannot isolate the itinerant business from developments in permanent film exhibition because these had a direct influence on the business opportunities of their travelling counterparts. What is more, the mainstream theatrical model of metropolitan film exhibition was taken as the norm by the industry itself as well as by the state, which had implications for the economic and social position of travelling showmen. The itinerant business was widely considered a substandard section of the market and this image of unprofessionalism was reinforced by the fact that many of them used $16 \mathrm{~mm}$ or $17.5 \mathrm{~mm}$ projectors. In France, the very designation of the $17.5 \mathrm{~mm}$ format as Pathé Rural situated itinerant exhibition as the alternative "other," implying a distinctive rural entrepreneurial identity and a deviation from the metropolitan norm. However, the boundaries between ambulant and permanent exhibition were often more fluid than industry practices and regulations by national trade organizations suggest. Small-town and rural entrepreneurs adapted to changing demand and spread their activities over a variety of formats, combining itinerant and (semi-) permanent exhibition. That said, tension between the two subsectors was frequent, especially in periods when cinema attendance was declining.

In the opening decades of the twentieth century, picture shows widely circulated throughout Europe, but fixed sites permanently engaged in film exhibition remained scarce outside the main cities and metropolitan conglomerations, with the exception of Britain (Hanson 2007, p. 17). On the continent, 
cinema construction in small towns commenced in earnest in the early 1920s. Especially in France, this boom was part of a larger process of rural modernization, including electrification, street paving and the construction of new schools, community halls and other public buildings and squares. In the interwar years, many a small French town underwent an architectural makeover to shed its rural image (Marache 2006). Geography and demographics were determining influences in the emergence of stationary film venues in the countryside. Their number and regional distribution varied greatly between and within countries, depending on such factors as religion and the degrees of rural industrialization and urbanization. In the Protestant north of the Netherlands, for instance, the threshold for operating a permanent cinema was about 10,000 inhabitants (Thissen 2016). In the Catholic south, on the other hand, the economic conditions for opening a movie theatre were better because there was no structural social or religious resistance to the film medium. In the province of Limburg (98\% Roman Catholic), the density of moving picture theatres was the highest in the country and several small towns had more than one movie theatre.

With the rapid multiplication of permanent cinemas, itinerant exhibitors lost the most lucrative urban markets and hence their business became more and more precarious. Within a few years, tent shows were no longer profitable because the receipts no longer justified the high transportation costs (Baudet et al. 1974). Some exhibitors opened a stationary movie theatre, while others left the film sector. A minority continued to tour the country with portable projection equipment, trying to stay in the business of travelling cinema despite a rapidly changing industry. During the 1920s, they were further pushed to the margins of the market, to small towns and villages where the demand was not sufficient to support a permanent cinema. In remote regions with scattered villages and hamlets, itinerant exhibition remained the most efficient format. Depending on the local situation, the itinerant exhibitors collaborated with innkeepers, churches, municipalities and a wide range of secular and religious associations that had embraced the cinema for 
education and entertainment. Some specialized in the not-forprofit sector, but the majority seems to have picked up any opportunity to earn some money. Regardless of the parties involved, the alliances were meant to be mutually beneficial. For innkeepers and café owners, the screenings brought in extra clientele at the bar and income from the rental fee or a percentage of the receipts (or a combination of both). Travelling film exhibitors used the existing infrastructure, which saved operating costs, and they benefited from advance publicity. Posters were plastered on key points in the village or town and in front of the venue. Handbills were distributed in the streets and put on shop windows. When exhibitors worked with grassroots associations or churches, the collaboration reinforced prospective patrons' confidence in the moral quality of the show and weakened anti-cinema sentiments among conservative forces in the local community. Churches, municipalities and voluntary organizations typically used the screenings as fundraising events to sponsor less lucrative recreational activities. Worth mentioning in this context is the well-documented history of film screenings in the hundreds of multifunctional halls owned by the local divisions of the Swedish temperance and labour movements - a tradition that persists until this day (Jernudd 2005, Jernudd and Lundmark 2016).

The breakthrough of sound cinema spurred a second wave of cinema construction in big cities and small towns alike. The conversion to sound also gave the itinerant sector a new impulse. However, a closer look at individual trajectories suggests that for the remaining travelling showmen of the fairground era, the introduction of talking pictures often heralded the end of their career in film exhibition. They probably did not have enough financial resources to buy new equipment. The travelling exhibitors who took the lead in the 1930s often came from the café-restaurant-hotel business or already operated a permanent movie theatre from which they expanded their activities in the itinerant trade (Marache 2016, Thissen 2016, van Oort 2016).

In retrospect, the 1930s marked the beginning of a long period of continued growth in small-town and rural film exhibition 
in the three countries under consideration. On the eve of the Second World War, approximately one-third of the permanent cinemas in the Netherlands were located in communities with fewer than 20,000 inhabitants. In other communities, proprietors of hotels renovated their halls and installed permanent projectors and fixed chairs. During the weekend, they either operated these makeshift cinemas themselves or leased the premises to a travelling exhibitor. The new generation of travelling enterprises began to move away from genuine itinerancy and increasingly organized their tours into stable exhibition circuits, regularly visiting the same localities. It is in this period that we begin to find small announcements in local newspapers, informing the audience about the play dates of specific feature films, a practice that became more common after the war. In France too, the number of halls used for film screenings expanded rapidly in the 1930s. New municipal halls were opened across the country, like the salle des fêtes in Saint-Laurent-duMédoc. The decade also witnessed the explosive growth of Catholic parish halls. Many of these new multipurpose buildings functioned primarily as a film venue. By 1938, there were around 1,500 parish cinemas in France, with strong concentrations in Bretagne and the Centre region (Leventopoulos 2016). The situation in Germany was distinct because of the political situation. In 1935, 32.1\% of the movie theatres were located in towns with fewer than 5,000 inhabitants-a significant figure from the perspective of film circulation. It still meant, however, that only $2.8 \%$ of such communities had a fixed movie theatre (Faber 1957, p. 30). This limited film exhibition infrastructure was problematic for the Nazi regime, which had singled out the movies (along with the radio) as a key instrument for propagan$\mathrm{da}$, especially among rural populations. Moreover, they anticipated that the implementation of modern mass media would make village life more attractive and thus stop rural desertion for the big cities. Hence, a huge network was set up with over 22,000 mostly private venues that could be used for film screenings supervised by the National Socialist Party (NSDAP). After 1945 , many of these continued to offer weekly movie nights (Paech 1985, Zimmermann 1999 and 2001). 
It will come as no surprise that the expansion of itinerant business activity and the growing number of film screenings in multifunctional halls alarmed the owners of permanent theatres. In France, every now and then there was an outburst of complaints about unfair competition, especially from the growing number of not-for-profit screenings by the Catholic Church and secular associations and from the involvement of municipalities in film exhibition (Forest 1995, pp. 53 and 73-74). In the Netherlands, Catholic film venues were a source of concern in the early 1920s because their not-for-profit status exempted them from paying local amusement tax, whereas commercial theatres were taxed up to $30 \%$ on the box-office returns. In the 1930s, when business conditions deteriorated under the combined impact of the economic recession and growing competition from newcomers, theatre owners asked the Netherlands Cinema League (NBB) to curb the activities of travelling exhibitors. Distributors protested fiercely, but to no avail. In 1935, in the context of a broader effort to regulate the market and reduce competition, it was decided that travelling exhibitors could only organize two screening days per month (or 24 per year) in the same municipality. No more than 18 of these could be held in the same building, which was a serious impediment to the development of weekend cinemas in hotel halls (van Oort 2016).

In most regions of Europe, film exhibition was barely interrupted by the Second World War except in the first months and then again in the last year. In fact, the German Occupation prompted both the expansion and the professionalization of itinerant film exhibition. In France, the German authorities prohibited the $17.5 \mathrm{~mm}$ format in 1941 and imposed conversion to $16 \mathrm{~mm}$ on the 3,500 outlets equipped with the Pathé Rural. This compulsory standardization facilitated the circulation of copies and fostered the expansion of film exhibition in small communities (Forest 1995, pp. 63-64 and 79). In the Netherlands, where the NBB had temporarily lost its cartel-like control over the market, there was explosive growth of film venues in the countryside between 1942 and 1944. True itinerant cinema was prohibited because it was difficult to control, but under the watchful eye of 
the Film Guild of the Dutch Kulturkammer, exhibitors expanded their existing circuits or set up new ones. Most newly opened film venues in multifunctional halls remained in business after the Liberation (Dibbets 1980, pp. 48-49).

\section{Post-war Boom and Bust}

The fifteen years following the end of the Second World War constituted the golden age of small-town and rural cinema in continental Europe. Audiences in the hinterlands, especially young people, participated more fully in the mass culture of the movies than ever before. To satisfy the increased demand, itinerant film exhibitors and circuits that combined permanent and semi-permanent exhibition began to run "weekend cinemas" in multifunctional halls in localities which before the war were only visited once a week or twice a month or with no regularity at all. The majority of these weekend cinemas or "hotel cinemas" (depending on whether one emphasized time or space) were situated in villages where the demand was still not high enough to run a permanent cinema. Most of them offered between four and eight screenings per week, including matinees for children. In the Netherlands and Germany, hotel cinemas were typically located in communities with 2,000 to 5,000 inhabitants. Below the threshold of 2,000, there was only enough patronage for a weekly screening. In the latter context, the communities were typically integrated in a circuit which was visited each week on a fixed night, often on weekdays so that the copy could be used in the larger localities during the weekend.

By the early 1950s, the Dutch market for travelling shows was dominated by a small number of large, family-owned regional chains, most of which combined travelling and stationary exhibition. All itinerant showmen were part of the Netherlands Cinema League and hence formally integrated into the mainstream industry. They operated primarily in fully equipped hotel cinemas. For screenings in halls that were visited once a week or twice a month, the projectionist still needed to bring along his own projector. Even these minor venues, however, had fixed screens, folding chairs and blackout curtains. In the late 1950s, some rural municipalities opened a brand new 
multifunctional "theatre-cinema" and rented it out to a commercial film exhibitor for a large part of the week. The rationale behind these public-private partnerships was that a cinema would keep life in the village attractive, especially for young people. Liveability was not the only motive, however. It was also a means to generate income. Although amusement taxes varied locally, the standard rate on film screenings was $35 \%$ of the gross revenue. This percentage dropped significantly in the late 1950 s and early 1960s after complaints from exhibitors who were hard pressed to keep their business profitable as a result of declining cinema attendance. For the same reason, the building projects for most municipal cinemas were never carried out.

In post-war France, the modernization of the countryside accelerated thanks to the combined efforts of the public and private sectors. A new building boom of permanent cinemas was one of the effects. Similar to the Netherlands but on a much larger scale, French municipalities invested in modern community halls, often embracing again the latest trends in architecture. Unlike in the Netherlands, independent "one-man" enterprises continued to dominate the business of travelling cinema. Sometimes, a local travelling circuit was part of a larger regional chain. For instance, in the Gironde and Dordogne, Jean Usureau, who had started out with a travelling show just after the First World War, built up a chain of permanent small-town cinemas in the late 1940s, while his son and a nephew remained active in the field of itinerant film exhibition (Marache 2016). For these young men, who were sometimes accompanied by their wives, life on the road was hard and required a lot of improvisation and perseverance. Although somewhat idiosyncratic because he worked without a licence and showed mostly old slapstick comedies which he owned, the remarkable memoir Le cinéma ambulant en Provence by François Morenas (1981) gives us good insight into the precarious working conditions of these rural showmen. Circuits of 150 to 250 kilometres each week were not uncommon. Corinne Marache (2016) interviewed Guy Modon (born 1928), who toured the rural Gironde in the 1940s and 1950s. On Mondays, he would pick up a new set of films in Bordeaux and the remainder of the week he was 
on the road, initially travelling by bike and later by motorcycle. None of the villages and towns he visited on his weekly tour had a permanent cinema. The venues used by Modon and Morenas were plain halls that frequently lacked basic facilities like heating, a screen and curtains to darken the room. Sometimes there was no projection booth, so they had to put the projector outside and project through the open window.

Due to wartime destruction and severe economic scarcity in the immediate post-war years, itinerant exhibitors in Germany also had to work in trying circumstances (Paech 1985; Gruttmann 2016). At the same time, it was a period that offered ample opportunities because many permanent movie theatres were destroyed. Those who had collaborated too closely with the Nazi regime had to wait a few years to get a new licence, but others took up their trade soon after the war had ended. Paech found that in the surroundings of the Osnabrück region, three Wanderkino businesses were active in the 1940s and 1950s. They still travelled around with their projection equipment-often in a three-wheeler Tempo with three people squeezed in the front. Only the largest halls were equipped with fixed screens, so they had to build up everything each night and then pack their equipment again after the last show. Two screenings were the norm: one at 6:00 p.m. for youth and a second film at 8:00 p.m. Circuits were rarely larger than seven villages. The program would be changed every week as they catered to the same local audiences. For several years, these "mom-and-pop" businesses managed to earn a decent living. When it was financially possible to invest in a fixed site they often turned to stationary exhibition or a combination of a permanent movie theatre and satellite shows once a week in the surrounding villages. By the mid-1950s, purpose-built movie theatres mushroomed in the German countryside. This boom not only signified widespread confidence in the Wirtschaftswunder, but also in the future of cinema. As seen elsewhere in continental Europe, however, attendance began to decline in the late 1950s, with 1958 marking the start of a long period of steep decline. By the late 1960s, many of the almost brand new cinemas had been turned into supermarkets or discos, and most travelling businesses had vanished. 


\section{Patterns and Preferences in Film Consumption}

Audiences in the countryside were included in the medium's mass market, but choice and access to cinematic entertainment remained limited even during the post-war boom. In the city, one could go to see a film any day of the week and almost any time of the day. As we saw, in many villages the itinerant exhibitor only passed by once a week on a fixed day. When there was a permanent movie theatre in town, this did not mean that one could go to the movies every day. Before the war, many permanent cinemas in the Netherlands were only open during the weekend. Some exhibitors offered an additional matinee on Sunday afternoon; others extended their program to Monday night or offered an additional screening on Wednesday afternoon when schools were closed. In 1932, fewer than half of the Dutch cinemas operated on a daily basis. Moreover, outside the main cities many permanent movie theatres closed down entirely during the summer. Film statistics for West Germany show that in the early 1950s around a quarter of the permanent movie theatres were operating no more than four days per week (Faber 1957, p. 33).

Metropolitan audiences and people who lived in the main provincial cities had a large selection of films to choose from. In rural small towns and villages, there were at best two feature films on the program each week. These films were rarely recent releases, because the latest productions were too expensive for exhibitors in the countryside. Even the news was often old news. A German travelling exhibitor explained that he used to show newsreels in their fourth or fifth week, because he could not afford the rental fee for the latest news (Paech 1985, p. 101). Although further research into programming is necessary, the existing studies suggest that national feature films reached rural audiences sooner than Hollywood movies and European imports. In respect to film culture in rural Sweden, Jernudd and Lundmark (2016, p. 80) convincingly argue that rural audiences found it "important that Swedish releases were up-to-date, so that they could keep up with the coverage in newspapers, film journals and other mass media." Small-town and rural film fans in other European countries probably 
thought the same. So did the exhibitors. However, the relatively small size of their potential audience and their patrons' modest budgets seriously limited their negotiation power with distributors. Block booking practices further reduced the possibility to adapt their programs to the preferences of their patrons, whose taste tended to be more conservative and less sophisticated than those of urban audiences.

Religious habits and beliefs shaped rural film culture in significant ways. In villages and towns with a (semi-) permanent film venue, Sunday was the best day of the week. Not without reason, priests and ministers but also parents and youth organizations saw the popularity of the movies as a serious threat to churchgoing. Hence, some churches and religious associations organized their own Sunday shows with educational and religious films, but it seems that these alternative screenings primarily attracted younger children. The clergy's strong grip on social life may have frustrated some exhibitors, but most of them adjusted their exhibition and programming practices to avoid open conflicts with local dignitaries (Gruttmann 2016). Exhibitors eagerly programmed rural blockbusters like The Song of Bernadette (Henri King, 1943), Le petit monde de don Camillo (Don Camillo, Julien Duvivier, 1952) or Die Trapp-Familie (The Trapp Family, Wolfgang Liebeneiner, 1956). In Catholic regions in France and Germany, exhibitors fitted the schedule of their Sunday shows to the times of churchgoing: the first screening was programmed before Vespers, the second one afterwards (Leventopoulos 2016; Faber 1957). With the shortening of the work week, Saturday night shows gained popularity, but they did not surpass Sunday attendance. Faber (1957, p. 34) explains that in the village people who worked in agriculture did not have an "early weekend" like people in town.

Finally, the time of year was another key factor in determining film consumption in the countryside. For many people in villages and towns in rural Europe, the availability of time for leisure was intimately bound up with the rhythms of agriculture. Especially when a large part of the population worked on the land or in the agro-industry, cinema attendance was subject to strong seasonal fluctuations. As a rule, film screenings 
attracted fewer people from March to the end of September. Attendance dropped sharply during harvest periods. In the winter, when farm work slowed down, people had more time to go the movies. Permanent movie theatres and itinerant film exhibitors adapted to this fluctuation in demand. The winter season had its own problems, however, because bad weather conditions often had a negative impact on attendance and sometimes forced itinerant operators to cancel their show.

\section{Conclusion: What Is a Cinema?}

Writing the rural and small-town experience of movie-going into film history is not only "an exercise of empiricist comprehensiveness," as Robert C. Allen (2006, p. 64) reminds us. It also calls for a new conceptualization of "the relationship between cinema and place more generally." On the one hand, understanding the place of cinema in the countryside requires rethinking cinema's relationship to the city and urban modernity (e.g. Allen 2008; Aveyard 2011). On the other, it requires us to reconsider our assumptions about what a cinema is.

Drawing on insights from digital cinema historiography, Deb Verhoeven (2013, p. 46) proposes in "What is a cinema? Death, closure and the database" to no longer view a cinema as a stable place or entity characterized by a set of predefined parameters, but to define it in relational terms: as "a series of events where 'place' happens." By radically shifting the perspective on the notion of place, she emphasizes both the temporality and mutability of cinemas (changes of property, location, programming practices, audiences etc.) and the fact that "the cinema cannot be isolated from its surroundings or from its networks (of audiences, films, amenities and so on)." Verhoeven wrote her essay in reaction to contemporary debates about the future of cinema in the digital age. Both within and without the film industry, the current debate is haunted by the spectre of death and "desolate stories of an authenticity lost" as a consequence of digital cinema technology and new business practices (ibid., p. 39). Particularly striking in this respect, as Verhoeven points out, are commentaries that equate the end of the traditional mode of film exhibition with the end of the medium itself. What I like 
about her bold response to this pessimistic thinking is that she radically breaks away from essentialist assumptions about what a cinema is (and what cinema is too). A similar uneasiness with the "double birth" thesis prompted me to the question at the beginning of this article if the salle des fetes of Saint-Laurent-duMédoc and the Hofgarten Lichtspiele are cinemas or not. What if we were to abandon the notion that the singularity of the cinema somehow coincides with the type of motion picture theatre that emerged during cinema's second birth? What if we take the view instead that "the place of cinema" is the effect of particular social, cultural and economic practices that come together at a certain moment in time in a specific locality and community? As one German travelling exhibitor explained, "once a week, it was cinema time, never mind where, and even if it was only a ramshackle hall—we made cinema!" (quoted in Paech 1985, p. 101). In the case of multipurpose halls, the cinema was but one of a series of events happening under the same roof and hence the public's experience of movie-going was necessarily intertwined with other communal and commercial activities. Cinema's social meaning and cultural identity are co-produced by this context. But a permanent movie theatre too is always inscribed in a network of people, places, practices and processes. An approach that takes these broader contexts and interrelations into account would help us to better understand the diversity of rural and urban experiences of movie-going, in the past as well as today.

Universiteit Utrecht

\section{BIBLIOGRAPHICAL REFERENCES}

Allen 2006: Robert C. Allen, “Relocating American Film History: The 'Problem' of the Empirical," Cultural Studies 20:1 (2006), pp. 48-88.

Allen 2008: Robert C. Allen, "Decentering Historical Audience Studies: A Modest Proposal," in Fuller-Seeley 2008, pp. 20-33.

Aveyard 2011: Karina Aveyard, "What the Country Tells Us: The Place of the 'Rural' in Contemporary Studies of Cinema," Media International Australia 139 (2011), pp. 124-32.

Baudet et al. 1974: Henri Baudet in collaboration with J.W. Drukker, P. Kooij, H. van der Meulen, S. de Vries, and W.G. Whitney, "Consumenten en innovaties (II): 
Een nieuwe benadering van historisch consumentengedrag," Maandschrift Economie (August-September 1974), pp. 612-26.

Braun et al. 2012: Marta Braun, Charles Keil, Rob King, Paul Moore and Louis Pelletier (eds.), Beyond the Screen: Institutions, Networks and Publics of Early Cinema, New Barnet, John Libbey Publishing, 2012.

Dibbets 1980: Karel Dibbets, "Bioscoopketens in Nederland: Economische Concentratie en Geografische Spreiding van een Bedrijfstak, 1928-1977," master's thesis, Universiteit van Amsterdam, 1980.

Faber 1957: Werner Faber, "Filmbesuch und Filmbesucher im Dorf," in Walter Hagemann (ed.), Film Studiën 3, Emsdetten, Lechte, 1957, pp. 27-44.

Forest 1995: Claude Forest, Les dernières séances. Cent ans d'exploitation des salles de cinéma, Paris, CNRS, 1995.

Fuller-Seeley 2008: Kathryn H. Fuller-Seeley (ed.), Hollywood in the Neighborhood: Historical Case Studies of Local Moviegoing, Berkeley, University of California Press, 2008.

Fuller-Seeley and Potamianos 2008: Kathryn H. Fuller-Seeley and George Potamianos, "Introduction: Researching and Writing the History of Local Moviegoing," in Fuller-Seeley 2008, pp. 3-19.

Gaudreault and Marion 2005: André Gaudreault and Philippe Marion, "A Medium is Always Born Twice," Early Popular Visual Culture 3:1 (2005), pp. 3-15.

Gruttmann 2016: Dörthe Gruttmann, "Film Culture and the Catholic Milieu in the Münsterland: Billerbeck and Telgte in the 1950s," in Thissen and Zimmerman 2016, pp. 38-51.

Hanson 2007: Stuart Hanson, From Silent Screen to Multi-Screen: A History of Cinema Exhibition in Britain since 1986, Manchester, Manchester University Press, 2007.

Jernudd 2005: Åsa Jernudd, "Reform and Entertainment: Film Exhibition and Leisure in a Small Town in Sweden at the End of the Nineteenth Century," Film History 17:1 (2005), pp. 88-105.

Jernudd and Lundmark 2016: Åsa Jernudd and Mats Lundmark, "Cinemagoing in Sweden in the 1940s: Civil Society Organizations and the Expansion of Rural Film Exhibition," in Thissen and Zimmerman 2016, pp. 67-86.

Leventopoulos 2016: Mélisande Leventopoulos, "Catholic Cinephilia in the Countryside: The Jeunesse Agricole Chrétienne and the Formation of Rural Audiences in 1950s France," in Thissen and Zimmerman 2016, pp. 165-80.

Marache 2006: Corinne Marache, "Les petites villes, pôle de dynamisme en milieu rural ? L'exemple aquitain, milieu XIX ${ }^{e}$-début $\mathrm{XX}^{\mathrm{e}}$ siècles," Histoire urbaine 15:1 (2006), pp. 93-114.

Marache 2016: Corinne Marache, "Cinema and Everyday Life in the Rural Gironde," in Thissen and Zimmerman 2016, pp. 105-16.

Moore 2013: Paul S. Moore, "The Grand Opening of the Movie Theatre in the Second Birth of Cinema," Early Popular Visual Culture 11:2 (2013), pp. 113-25.

Morenas 1981: François Morenas, Le cinéma ambulant en Provence, Lyon, Presses universitaires de Lyon, 1981.

Paech 1985: Anne Paech, Kino zwischen Stadt und Land, Marburg, Jonas, 1985.

Thissen 2013: Judith Thissen, "Understanding Dutch Film Culture: A Comparative Approach," Alphaville 6 (Winter 2013), http://www.alphavillejournal.com/ Issue6/HTML/ArticleThissen.html.

Thissen 2016: Judith Thissen, "Film Consumers in the Country: The Business and Culture of Cinemagoing in the Netherlands," in Thissen and Zimmerman 2016, pp. 87-104. 
Thissen and Zimmerman 2016: Judith Thissen and Clemens Zimmermann (eds.), Cinema Beyond the City: Small-Town and Rural Film Culture in Europe, London, BFI, 2016.

Van Oort 2016: Thunnis van Oort, "'Coming up this Weekend': Ambulant Film Exhibition in the Post-War Netherlands," in Thissen and Zimmerman 2016, pp. 149-64.

Verhoeven 2013: Deb Verhoeven, "What is a Cinema? Death, Closure and the Database," in Karina Aveyard and Albert Moran (eds.), Watching Film: New Perspectives on Movie-going, Exhibition and Reception, Bristol, Intellect, pp. 33-51.

Zimmermann 1999: Clemens Zimmermann, "Städtische Medien auf dem Land. Zeitung und Kino von 1900 bis zu den 1930er Jahren," in Clemens Zimmermann and Jürgen Reulecke (eds.), Die Stadt als Moloch? Das Land als Kraftquell?, Basel, Birkhäuser, 1999, pp. 141-64.

Zimmermann 2001: Clemens Zimmermann, "Landkino im Nationalsozialismus," Archiv für Sozialgeschichte 41 (2001), pp. 231-43.

\section{RÉSUMÉ}

\section{Les salles multifonctionnelles et la place du cinéma dans la campagne européenne, 1920-1970 Judith Thissen}

Prenant pour point de départ et d'arrivée la question «qu'est-ce qu'un cinéma?", et reconsidérant la notion de seconde naissance du cinéma, cet article étudie les rapports économiques et socioculturels de l'exploitation et de l'expérience cinématographiques dans les petites villes et les zones rurales d'Europe occidentale, en particulier aux Pays-Bas, en Allemagne et en France. L'accent est mis sur l'histoire du cinéma ambulant présenté dans des lieux multifonctionnels dans la période qui a suivi celle des foires - un aspect important de la culture cinématographique européenne qui a longtemps été négligé par les historiens du cinéma. Un aperçu de ces expériences particulières du cinéma peut nous aider à reconsidérer la place de ce dernier dans les contextes ruraux et urbains. Un aspect crucial de la projection de films est le fait qu'elle prenait place dans des lieux multifonctionnels, c'est-à-dire des espaces utilisés pour un large éventail d'activités commerciales et communautaires. L'auteur préconise ainsi une nouvelle historiographie du cinéma qui rompt avec la fixation sur la singularité du médium pour inclure sa relation avec les contextes socioculturels environnants dans lesquels il prend place. 